\title{
Effect of Thai Folklore Recipe from Abutilon indicum and Mimosa pudica in Streptozotocin-Induced Diabetic Rats
}

\author{
Ampa Konsue ${ }^{1 *}$, Chusri Talubmook ${ }^{2}$
}

\section{Ampa Konsue ${ }^{1 *}$, Chusri Talubmook ${ }^{2}$}

'Faculty of Medicine, Mahasarakham University, Maha Sarakham, THAILAND. ${ }^{2}$ Department of Biology, Faculty of Sciences, Mahasarakham University, Maha Sarakham, THAILAND.

Correspondence

Dr. Ampa Konsue

Faculty of Medicine, Mahasarakham University, Maha sarakham, 44000 THAILAND.

Phone: +66 43712992

E-mail: ampa_ice@hotmail.com

History

- Submission Date: 09-11-2017;

- Review completed: 18-12-2017;

- Accepted Date: 06-01-2018

DOI : 10.5530/pj.2018.3.79

Article Available online

http://www.phcogj.com/v10/i3

\section{Copyright}

(c) 2018 Phoog.Net. This is an openaccess article distributed under the terms of the Creative Commons Attribution 4.0 International license.

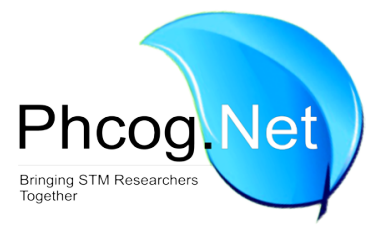

\begin{abstract}
Context: Abutilon indicum and Mimosa pudica were a folklore recipe in Northeastern of Thailand. The recipe was reported that claim to diabetic treatment. Aims: The studies were evaluated to hypoglycemic effect, serum insulin secretion and blood biochemistry in streptozotocin (STZ)-induced diabetic rats. Materials and Methods: The recipe were composed of whole plants from $A$. indicum and $M$. Pudica $(1: 1 \mathrm{w} / \mathrm{W})$ powder. The pound plants were macerated with aqueous (AMA), hydro-ethanol (AMHE) and $80 \%$ ethanol (AME) to crude extracts. The AMA, AMHE and AME at the doses of 125, 250 and $500 \mathrm{mg} / \mathrm{kg}$ body weight (b.w.) were administered orally daily in diabetic rats during eight weeks. Fasting blood glucose levels (FBG) were measured at weekly. The serum insulin levels and blood biochemical data including blood urea nitrogen (BUN), creatinine (CREA), total protein (TP), albumin (Alb), serum aspartate aminotransferase (AST), serum alanine aminotransferase (ALT), alkaline phosphatase (ALP), triglycerides (TG), total cholesterol (TC), high-density lipoprotein (HDL) and low-density lipoprotein (LDL) were estimated at the end of experiment. Results: All doses of the extracts were showed significantly $(p<0.05)$ decreasing percent age of FBG in diabetic rats. Especially, AME $125 \mathrm{mg} /$ $\mathrm{kg}$ b.w. was showed more potent significantly $(\mathrm{p}<0.05)$ decreasing percentage of FBG at week of 2, 5, 7 and 8 . The serum insulin levels of all doses administered with the extracts were significantly $(p<0.05)$ higher than diabetic control group. On the other hand, all doses of the extracts were significantly $(p<0.05)$ decreasing ALT and ALP lower than diabetic control group. While, AMA and AMHE at the doses of 250 and $500 \mathrm{mg} / \mathrm{kg} \mathrm{b.w.} \mathrm{were} \mathrm{increased} \mathrm{HDL,} \mathrm{but} \mathrm{decreased}$ TC, TG and LDL. Conclusion: The study was proved to diabetic treatment and improvement of diabetic stage and blood biochemical parameters. In addition, the experiment was confirmed to folklore traditional use.
\end{abstract}

Key words: Thai folklore recipe, A. indicum, M. pudica, Fasting blood glucose.

\section{INTRODUCTION}

Diabetes mellitus (DM) is a group of chronic metabolic disease characterized by hyperglycemia resulting from defects in insulin secretion, often combined with insulin action, or both. The chronic hyperglycemia of diabetes is associated with long-term damage, dysfunction and failure of various organs and systems. ${ }^{1}$ Diabetes requires continuous medical care and patient self-management education in order to prevent acute complications and to reduce the risk of long-term complications. ${ }^{2}$ Oral anti-diabetic agents are not only expensive, but also have undesirable side effects or contraindications. ${ }^{3}$ Diabetic patients often seek complementary therapy such as herbal medicines. In Thailand, several herbal medicines have been documented support as diabetic treatment. ${ }^{4}$ Many Thai medicinal plants have been used as the traditional medicines for management of diabetes. A Thai folklore recipe consist with M. pudica (MAIYA-LAP) and A. indicum (KHOB-FUN-SRI) have also been reported as being effective in diabetic treatment.
M. pudica or the sensitive plant is a medicinal plant belonging to the family Fabaceae. The plant was found to grow in undisturbed shady areas, under trees or shrubs. ${ }^{5}$ The most important biologically active constituents of this plants are alkaloids, steroids, tannins, flavonoids, glycosides and saponins compounds. ${ }^{6}$ The wide range of pharmacological activities of this plant have been reported including wound healing, ${ }^{7,8}$ analgesic, anti-inflammatory, ${ }^{9}$ anticonvulsant, ${ }^{10}$ anti-diarrhea, ${ }^{6,11}$ anti-oxidant, ${ }^{5,9,12,13}$ hepatoprotective, ${ }^{13,14}$ hypolipidemic, ${ }^{15,16}$ diuretic property, ${ }^{17}$ hypoglycemic ${ }^{5,18-20}$ and hyperglycemia activities. ${ }^{21}$

A. indicum Sweet is belonging to the family Malvaceae. The plants is an erect, woody, shrubby plant, widely distributed in the tropical countries and has a long medical history of being used as an anti-diabetic remedy. ${ }^{22}$ The components contained the natural substances such as amino acids, aliphatic compounds, sugars, polyphenols, flavonoids, alkaloids and glycosides. ${ }^{23}$ The plant is also reported to possess analgesic, ${ }^{24}$ hypoglycemic, ${ }^{25-29}$ hepatoprotective ${ }^{30}$ and antibacterial activity. ${ }^{31}$ With respect to its traditional 
Konsue, Talubmook.: Effect of Thai Folklore Recipe from Abutilon indicum and Mimosa pudica in Diabetic Rats

use in Thai traditional recipe, A. indicum and M. pudica should contain an active ingredient against diabetes and was believed to reduce some symptoms of diabetic complications. ${ }^{32}$

However, any signs or symptoms on diabetic treatment has not yet been demonstrated. Therefore, the purposes of this study were designed to determination of hypoglycemic effect and blood biochemical parameters using an different doses of a Thai folklore recipe that consist both whole plants of A. indicum and M. pudica in diabetic rats.

\section{MATERIALS AND METHODS}

\section{Collection of plant materials}

The fresh of whole plants (roots, stems, leaves, flowers and fruits) were harvested from Kalasin Province, Northeastern of Thailand. It was deposited at the Faculty of Medicine, Mahasarakham University, Thailand (code :: M. Pudica as MSU.MED-MP0001/AK ; A. Indicum as MED-AI0001/AK). The fresh plants were dried at $50^{\circ} \mathrm{C}$ for $48 \mathrm{hr}$ in a hot air oven then powdered.

\section{Preparation of crude extracts}

The aqueous extracts (AMA) were prepared by boiling dried plant powder from $A$. indicum and $M$. pudica $(1: 1 \mathrm{w} / \mathrm{w})$ in distilled water $(1: 10$ $\mathrm{w} / \mathrm{v}$ ) at $100{ }^{\circ} \mathrm{C}$ for $30 \mathrm{~min}$ for 3 times. The hydro-ethanolic (AMHE) and ethanolic (AME) extracts were prepared by macerating dried plant powder in $50 \%$ ethanol and $80 \%$ ethanol $(1: 5 \mathrm{w} / \mathrm{v})$ for 7 days. The residue powder was excluded by using the filter papers. The extract was dried using a rotary evaporator (Heidolph Laborota 4000, Germany) followed by a freeze dryer (Christ Alpha 14, Germany) to get obtain dark brown extracts. The extracts were kept in the fridge at $4^{\circ} \mathrm{C}$ until be used.

\section{Preparation of animals}

Healthy adult male albino Wistar rats weighing between 150-200 g purchasing from the National Laboratory Animal Centre, Mahidol University, Thailand were used in this study. They were acclimatized in an air conditioned room at $23 \pm 2{ }^{\circ} \mathrm{C}, 12 \mathrm{~h}$ light/12 h dark cycle (350-400 Lux) and relative humidity of $50-55 \%$, and given with a standard chow and watered ad libitum for 7 days prior to the commencing experiment. The rats were maintained in accordance with the guidelines of the Committee Care and Use of Laboratory Animal Resource, National Research Council Thailand and approved in accordance with the advice of the Institutional Animal Care and Use Committee, Mahasarakham University (IACUC-MSU), Thailand (License No. 0005/2017).

\section{Induction of diabetic rats}

The animals were injected intra-peritoneally with a single dose of $65 \mathrm{mg} /$ kg b.w. STZ (Sigma Chemicals, St. Louis, MO) dissolved freshly in cold $20 \mathrm{mM}$ citrate buffer ( $\mathrm{pH} 4.5) \cdot{ }^{33} \mathrm{After}$ injection, they were provided with $2 \%$ sucrose solution for $48 \mathrm{~h}$ to alleviate the discomfort after initiating the hypoglycemic phase. Three days after injection, the rats were examined for FBG levels to confirm their diabetic stage. The rats showing FBG levels greater than $126 \mathrm{mg} / \mathrm{dL}$ were used in the experiments. ${ }^{34}$

\section{Experimental designs}

The animals were randomly divided into the following twelve experimental groups with eight animals in each. Group I was normal control rats treated orally with $2 \%$ Tween 80 ; group II was diabetic control rats treated orally with $2 \%$ Tween 80 ; group III was diabetic rats administrated orally with glibenclamide $0.5 \mathrm{mg} / \mathrm{kg}$ b.w.; group IV-VI were diabetic rats administrated orally with AMA at the doses of 125, 250 and $500 \mathrm{mg} / \mathrm{kg}$ b.w.; group VII-IX were diabetic rats administrated orally with AMHE at the doses of 125, 250 and $500 \mathrm{mg} / \mathrm{kg}$ b.w.; group X-XXII were diabetic rats administrated orally with AME at the doses of 125, 250 and $500 \mathrm{mg} / \mathrm{kg}$ b.w. The extracts and glibenclamide were suspended in
$0.5 \%$ Tween 80 and administered orally once a day for 8 weeks using an orogastric tube. The volume of administration was $1 \mathrm{~mL}$ for each animal.

\section{Determination of fasting blood glucose}

The rats were fasted overnight and then the blood samples were collected from the tail vein of the rats. FBG was measured weekly for 8 weeks with Glucometer (Accu-chek Performa, Roche, Germany).

Determination of serum insulin and blood

\section{biochemical data}

After 8 weeks of treatment, the rats were fasted overnight. They were sacrificed by cervical dislocation technique, and then blood samples were drawn from the rat's heart. The blood samples were centrifuged at 3500 rpm for $20 \mathrm{~min}$ to separate blood serum. The serum insulin levels was estimated using the radioimmunoassay kit (MP Biomedicals-Orangeburg, USA) and detected by an automatic gamma counter (Wallac 1470 Wizard, Perkin Elmer Instrument, Germany). The blood biochemical parameters include total cholesterol (TC), triglycerides (TG), high-density lipoprotein (HDL), low-density lipoprotein (LDL), blood urea nitrogen (BUN), creatinine, total protein, albumin, serum aspartate aminotransferase (ALT), serum alanine aminotransferase (ALT) and alkaline phosphatase (ALP) which were measured by an automatic blood chemical analyzer (BT 2000 plus, Germany).

\section{Statistical analysis}

The results were expressed as mean \pm standard error of mean (SEM). Statistical analysis was carried out using One-Way ANOVA followed by Duncan's new multiple range test. The criterion for statistical significance was at a p-value less than 0.05 .

\section{RESULTS}

\section{Fasting Blood Glucose Levels}

Table 1 shows the effect of various doses of AMA, AMHE and AME from Thai folklore recipe on percentage decreasing of FBG levels in rats. AME at the dose of $125 \mathrm{mg} / \mathrm{kg}$ b.w. showed significant highest percentage reduction of FBG levels in diabetic rats especially at the week 5, 7 and 8 which was greater than antidiabetic drug, glibenclamide and diabetic control groups. While, AMHE at the dose of $250 \mathrm{mg} / \mathrm{kg}$ b.w. produced a significant effect in lowering FPG which was showed at week 2 (12.22\%) and $4(9.31 \%)$ respectively. Pleasingly, at the week 4 , AMA at the dose $500 \mathrm{mg} / \mathrm{kg}$ b.w. and AME at the dose $125 \mathrm{mg} / \mathrm{kg}$ b.w were significant decreasing percentage of FBG higher than normal control, diabetic control and glibenclamide.

\section{Serum Insulin Levels}

Figure 1 shows the effect of various doses of AMA, AMHE and AME from Thai folklore recipe on serum insulin levels in rats after 8 weeks of administration. All doses of AMA, AMHE and AME showed serum insulin levels significant similar anti-diabetic drug, glibenclamide and were more potent higher than diabetic control group.

\section{Blood Biochemistry}

Table 2 shows the effect of various doses of AMA, AMHE and AME from Thai folklore recipe on the blood biochemistry : renal functions (BUN and CREA) and liver functions (TP, Alb, AST, ALT and ALP). AMA at the dose of $500 \mathrm{mg} / \mathrm{kg}$ bw and AMHE at the dose of $250 \mathrm{mg} / \mathrm{kg}$ bw showed significantly $(\mathrm{p}<0.05)$ reducing BUN compared to the diabetic control group. All the doses of AMA and AMHE (125 and $250 \mathrm{mg} / \mathrm{kg}$ bw) were decreased CREA in diabetic rats, On the other hand, all the doses of AME and AMHE $500 \mathrm{mg} / \mathrm{kg}$ bw were increased when compare with diabetic control and glibenclamide groups. The liver function data showed that $\mathrm{TP}$ and $\mathrm{Alb}$ in diabetic rats administered at the all doses of extract were not different from diabetic control rats. The AST in rats at the doses of AMA and AMHE $500 \mathrm{mg} / \mathrm{kg}$ bw were potent significantly 
Konsue, Talubmook.: Effect of Thai Folklore Recipe from Abutilon indicum and Mimosa pudica in Diabetic Rats

Table 1: Effect of Thai folklore recipe on percentage decreasing of fasting blood glucose levels in rats.

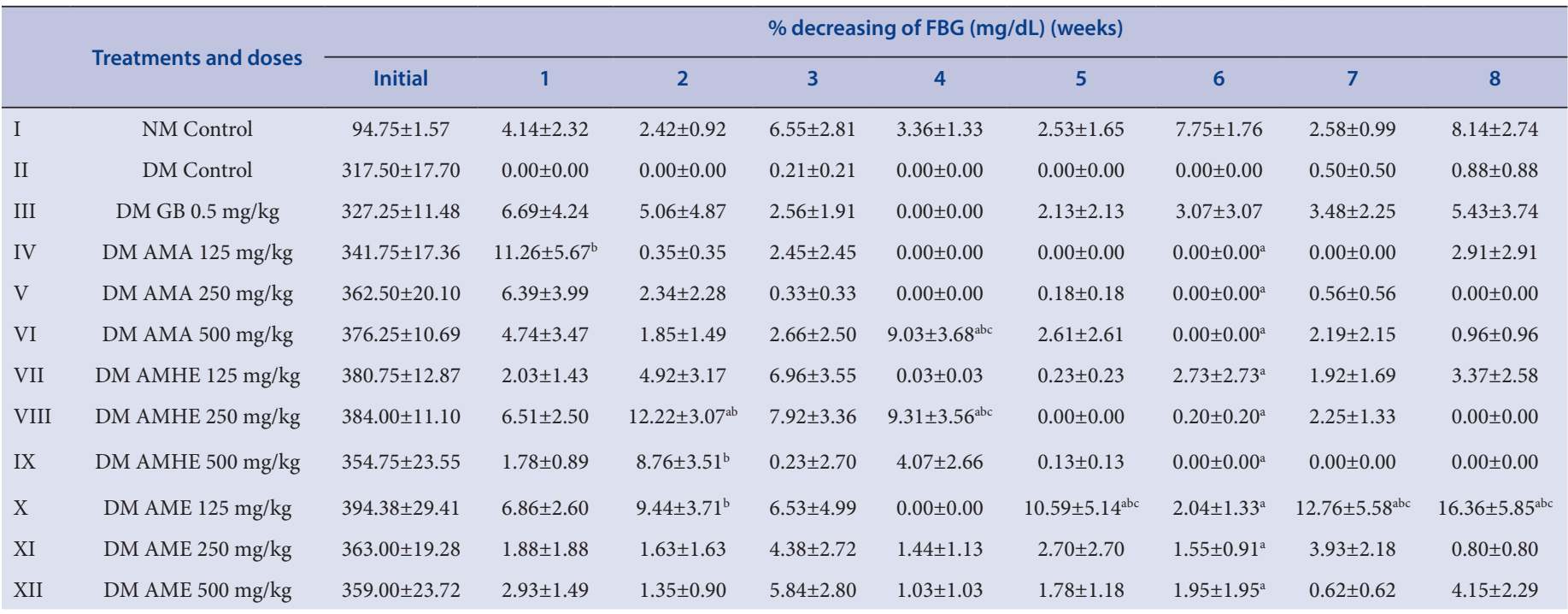

The results show the mean \pm SEM. ${ }^{a}$ represents statistical significance $(\mathrm{P}<.05)$ compared with normal control. ${ }^{\mathrm{b}}$ represents statistical significance $(\mathrm{P}<.05)$ compared with diabetic control. ' represent statistical significance $(\mathrm{P}<.05)$ compared with DM GB $0.5 \mathrm{mg} / \mathrm{kg}$.

Table 2: Effect of Thai folklore recipe on Blood biochemistry in rats.

\begin{tabular}{|c|c|c|c|c|c|c|c|c|}
\hline & \multirow{2}{*}{ Treatments and doses } & \multicolumn{2}{|c|}{ Renal functions } & \multicolumn{5}{|c|}{ Liver functions } \\
\hline & & BUN (mg/dL) & CREA (mg/dL) & $\mathrm{TP}(\mathrm{g} / \mathrm{dL})$ & Alb (g/dL) & AST (IU/L) & ALT (IU/L) & ALP (IU/L) \\
\hline I & NM Control & $20.48 \pm 0.80$ & $0.33 \pm 0.01$ & $6.58 \pm 0.06$ & $4.10 \pm 0.03$ & $107.00 \pm 1.36$ & $38.50 \pm 1.90$ & $89.50 \pm 2.81$ \\
\hline II & DM Control & $51.78 \pm 2.64$ & $0.26 \pm 0.02$ & $5.40 \pm 0.15$ & $2.73 \pm 0.09$ & $349.50 \pm 28.56$ & $57.63 \pm 3.36$ & $587.00 \pm 17.62$ \\
\hline III & DM GB 0.5 mg/kg & $42.73 \pm 3.33$ & $0.27 \pm 0.02$ & $5.85 \pm 0.28$ & $3.30 \pm 0.15$ & $299.50 \pm 12.53$ & $77.75 \pm 2.62$ & $460.00 \pm 20.16$ \\
\hline IV & DM AMA 125 mg/kg & $56.20 \pm 2.83^{\mathrm{ac}}$ & $0.25 \pm 0.02^{\mathrm{a}}$ & $5.55 \pm 0.17^{\mathrm{a}}$ & $2.85 \pm 0.04^{\mathrm{ac}}$ & $327.38 \pm 16.28^{\mathrm{a}}$ & $77.50 \pm 2.94^{\mathrm{ab}}$ & $346.13 \pm 21.88^{\mathrm{abc}}$ \\
\hline V & DM AMA 250 mg/kg & $58.78 \pm 3.34^{\mathrm{ac}}$ & $0.29 \pm 0.01$ & $5.63 \pm 0.18^{\mathrm{a}}$ & $2.80 \pm 0.06^{\mathrm{ac}}$ & $312.75 \pm 24.85^{\mathrm{a}}$ & $69.38 \pm 1.95^{\mathrm{ab}}$ & $474.38 \pm 11.48^{\mathrm{ab}}$ \\
\hline VI & DM AMA 500 mg/kg & $43.70 \pm 2.60^{\mathrm{ab}}$ & $0.29 \pm 0.01$ & $5.65 \pm 0.04^{\mathrm{a}}$ & $2.68 \pm 0.09^{\mathrm{ac}}$ & $240.63 \pm 13.43^{\mathrm{abc}}$ & $51.25 \pm 2.37^{\mathrm{ac}}$ & $281.38 \pm 17.25^{\mathrm{abc}}$ \\
\hline VII & DM AMHE 125 mg/kg & $53.50 \pm 2.46^{\mathrm{ac}}$ & $0.28 \pm 0.01$ & $5.90 \pm 0.08^{\mathrm{a}}$ & $2.95 \pm 0.04^{\mathrm{ac}}$ & $306.00 \pm 15.43^{\mathrm{a}}$ & $59.88 \pm 1.08^{\mathrm{ac}}$ & $422.00 \pm 16.96^{\mathrm{ab}}$ \\
\hline VIII & DM AMHE 250 mg/kg & $43.54 \pm 1.96^{\mathrm{ab}}$ & $0.27 \pm 0.01$ & $5.94 \pm 0.02^{\mathrm{a}}$ & $2.93 \pm 0.05^{\mathrm{ac}}$ & $313.00 \pm 35.25^{\mathrm{a}}$ & $70.75 \pm 1.92^{\mathrm{bc}}$ & $374.75 \pm 6.55^{\mathrm{abc}}$ \\
\hline IX & DM AMHE 500 mg/kg & $44.18 \pm 3.46^{\mathrm{a}}$ & $0.37 \pm 0.04^{\mathrm{bc}}$ & $5.68 \pm 0.08^{\mathrm{a}}$ & $2.90 \pm 0.06^{\mathrm{ac}}$ & $191.88 \pm 20.54^{\mathrm{abc}}$ & $38.75 \pm 2.14^{\mathrm{bc}}$ & $319.63 \pm 10.45^{\mathrm{abc}}$ \\
\hline $\mathrm{X}$ & DM AME 125 mg/kg & $55.20 \pm 3.28^{\mathrm{ac}}$ & $0.35 \pm 0.02^{\mathrm{bc}}$ & $5.43 \pm 0.22^{\mathrm{a}}$ & $2.65 \pm 0.19^{\mathrm{ac}}$ & $467.88 \pm 8.41^{\mathrm{abc}}$ & $107.63 \pm 4.38^{\mathrm{abc}}$ & $243.50 \pm 11.28^{\mathrm{abc}}$ \\
\hline XI & DM AME 250 mg/kg & $59.58 \pm 1.79^{\mathrm{ac}}$ & $0.38 \pm 0.03^{b c}$ & $5.25 \pm 0.12^{\mathrm{ab}}$ & $2.88 \pm 0.11^{\mathrm{ac}}$ & $426.00 \pm 7.01^{\mathrm{abc}}$ & $149.13 \pm 4.19^{\mathrm{ab}}$ & $366.25 \pm 7.40^{\mathrm{abc}}$ \\
\hline XII & DM AME 500 mg/kg & $44.08 \pm 1.34^{\mathrm{a}}$ & $0.34 \pm 0.01^{\mathrm{bc}}$ & $5.55 \pm 0.09^{\mathrm{a}}$ & $2.70 \pm 0.10^{\mathrm{ac}}$ & $375.50 \pm 5.86^{\mathrm{abc}}$ & $151.38 \pm 5.50^{\mathrm{ab}}$ & $215.50 \pm 6.98^{\mathrm{abc}}$ \\
\hline
\end{tabular}

$\mathrm{BUN}=$ blood urea nitrogen; $\mathrm{CREA}=$ creatinine; $\mathrm{TP}=$ total protein; $\mathrm{Alb}=$ albumin $; \mathrm{AST}=$ serum aspartate aminotransferase; $\mathrm{ALT}=$ serum alanine aminotransferase; ALP $=$ alkaline phosphatase

The values represent the mean \pm SEM. ${ }^{a}$ represents statistical significance $(p<0.05)$ compared with normal control. ${ }^{b}$ represent statistical significance $(p<0.05)$ compared with diabetic control. ${ }^{c}$ represent statistical significance $(p<0.05)$ compared with DM GB $0.5 \mathrm{mg} / \mathrm{kg}$.

lowering than diabetic control and glibenclamide rats. Especially, ALT in rats at the doses of AMHE $500 \mathrm{mg} / \mathrm{kg}$ bw showed produced similar to normal control rats. Moreover, all the doses of extracts were showed significantly decreasing ALP different from compare group, diabetic control and glibenclamide rats.

\section{Lipid Profiles}

Table 3 shows the effect of various doses of AMA, AMHE and AME from Thai folklore recipe on lipid profiles (TC, TG, HDL and LDL). All doses of the extracts were more potent significantly increasing HDL, decreasing LDL different from diabetic rats. TG in rats administered with all of the extracts exclude AME 250 and $500 \mathrm{mg} / \mathrm{kg}$ bw showed significantly $(\mathrm{p}<0.05)$ lower than the diabetic group which was almost equal to glibenclamide.

Only dose of AME $250 \mathrm{mg} / \mathrm{kg}$ bw was produced significantly decreasing TC different from diabetic control and glibenclamide. 


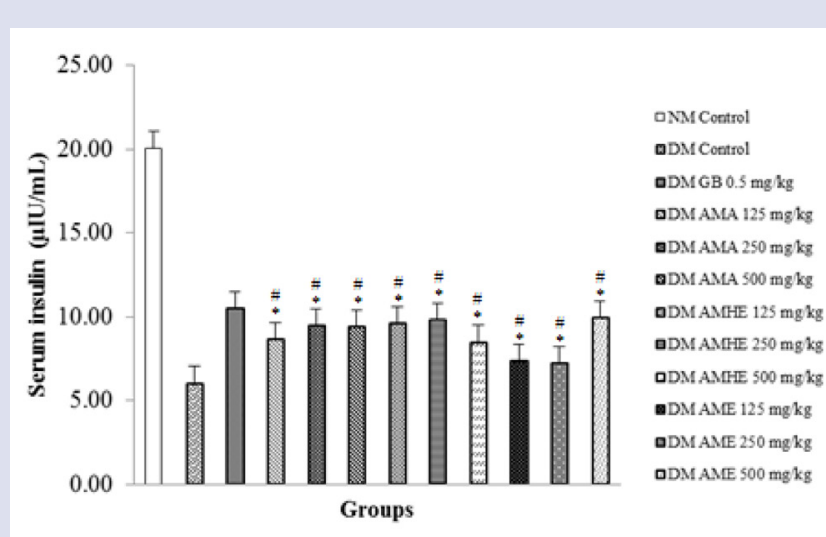

Figure 1: Effect of Thai folklore recipe at 8 weeks serum insulin levels in animal. The results show the mean \pm SEM. * Represents statistical significance $(p<0.05)$ compared with normal control. \# Represent statistical significance $(p<0.05)$ compared with diabetic control. X Represent statistical significance $(p<0.05)$ compared with DM GB $0.5 \mathrm{mg} / \mathrm{kg}$.

\section{DISCUSSION}

The present study was designed to investigate hypoglycemic effect of the Thai folklore recipe which contain of A. indicum and M. Pudica (1:1 $\mathrm{w} / \mathrm{w})$. The experiments were treated to comparing with current traditional medicine, anti-diabetic drug, glibenclamide to promote its traditional use for diabetic treatment. Furthermore, it was also tested for its any side effect or symptom on the renal functions, liver functions and lipid profiles in the rats. STZ ( $65 \mathrm{mg} / \mathrm{kg} \mathrm{bw}$ ) was selected in order to partially destroy the pancreatic $\beta$-cells. Under these conditions, insulin was secreted but not in an amount sufficient to regulate blood glucose levels and consequently, the rats became permanently hyperglycemic stage. STZ is a broad-spectrum antibiotic that separated from Streptomyces acromogenes. STZ has the cytotoxic effect on $\beta$-cells of pancreas. STZinduced diabetes has been described as a useful experimental model to study the anti-diabetic activity of several agents. ${ }^{35-36}$
The result showed that AM had a significant FBG reduction observed in STZ- induced diabetic rats by decreasing blood glucose levels but not in a dose dependent manner. AME at the dose of $125 \mathrm{mg} / \mathrm{kg}$ bw showed higher effect than glibenclamide $(0.5 \mathrm{mg} / \mathrm{kg} \mathrm{bw})$ especially at the 2, 5, 7 and 8 weeks. This result shows that AME at the dose of $125 \mathrm{mg} / \mathrm{kg}$ bw is approximately dosage which may be absorb into rat's digestive system. This assumption was proved in a further study by testing with various doses of AME below $125 \mathrm{mg} / \mathrm{kg}$ bw. The experiments were indicated to hypoglycemic effect might be improve in diabetic patients due to the recipe was stimulated insulin secretion similar anti-diabetic drug, glibenclamide group. ${ }^{37-39}$ The mechanism of this effect is probably to regeneration of pancreatic $\beta$-cells which are destroyed by streptotozin. ${ }^{35}$ The recipe, $A$. indicum and $M$. Pudica, the chemical components of the plants were revealed that any phytochemical of these composed with some antidiabetic substances including alkaloids, flavonoids, glycosides, saponins and tannins. ${ }^{6,23,35}$ Saponins and alkaloids could be inhibit glucose uptake, while flavonoids could be protect various cell types from oxidative stressmediated cell injury. ${ }^{36}$ The flavonoids such as kaempferol as well known chemical compound which improve insulin stimulating glucose uptake in mature 3T3L1 adipocytes and protect the body against free radicals, it is biologically plausible relation between flavonoids and low risk of diabetes. ${ }^{37}$ Glycosides could be stimulated insulin secretion as well..$^{25}$ These chemical substances in plants may be responsible for the anti-diabetic effects were observed in the study.

Moreover, the blood biochemical data were found that improve some renal and liver function such as BUN, AST, ALT and ALP. ${ }^{38}$ These results demonstrate that the recipe could be improve renal and liver damage 39,40 The renal dysfunction improvement could be justified by total protein increasing, as in diabetic individuals nephropathy is the main factor for protein excretion in urine. ${ }^{41-44}$ Diabetes has been a great influence on lipid metabolism caused by streptozotocin-induced as a result to increasing of TC and TG levels which observed by impaired with liver function from diabetic rat damage. ${ }^{44-45}$ Our data showed improvement of lipid profiles which increased HDL, decreased TC, TG and LDL in the diabetic rats. ${ }^{15,16,41}$ The plants could be prevent and treat disorders of diabetes which mainly responsible for mediating the formation by peroxi-

Table 3: Effect of Thai folklore recipe on Lipid profiles in rats.

\begin{tabular}{lccccc}
\hline & & \multicolumn{4}{c}{ Lipid profiles (mg/dL) } \\
\cline { 3 - 6 } & Treatments and doses & $\begin{array}{c}\text { Total } \\
\text { cholesterol } \\
(\text { TC) }\end{array}$ & $\begin{array}{c}\text { Triglycerides } \\
\text { (TG) }\end{array}$ & $\begin{array}{c}\text { High density } \\
\text { lipoprotein } \\
\text { (HDL) }\end{array}$ & $\begin{array}{c}\text { Low density } \\
\text { lipoprotein } \\
\text { (LDL) }\end{array}$ \\
\hline I & NM Control & $114.75 \pm 1.82$ & $193.00 \pm 7.27$ & $50.70 \pm 1.81$ & $25.45 \pm 1.48$ \\
II & DM Control & $162.00 \pm 5.54$ & $346.50 \pm 11.62$ & $38.63 \pm 1.98$ & $54.08 \pm 2.66$ \\
III & DM GB 0.5 mg/kg & $157.25 \pm 3.40$ & $287.50 \pm 8.91$ & $49.88 \pm 1.20$ & $49.88 \pm 2.19$ \\
IV & DM AMA $125 \mathrm{mg} / \mathrm{kg}$ & $154.50 \pm 2.49^{\mathrm{a}}$ & $298.00 \pm 3.62^{\mathrm{ab}}$ & $58.63 \pm 1.64^{\mathrm{abc}}$ & $36.28 \pm 3.05^{\mathrm{abc}}$ \\
V & DM AMA $250 \mathrm{mg} / \mathrm{kg}$ & $143.25 \pm 2.93^{\mathrm{abc}}$ & $260.00 \pm 11.43^{\mathrm{ab}}$ & $47.48 \pm 1.54^{\mathrm{b}}$ & $43.78 \pm 2.43^{\mathrm{ab}}$ \\
VI & DM AMA $500 \mathrm{mg} / \mathrm{kg}$ & $151.88 \pm 3.52^{\mathrm{ab}}$ & $281.50 \pm 11.54^{\mathrm{ab}}$ & $58.51 \pm 1.93^{\mathrm{abc}}$ & $37.06 \pm 2.64^{\mathrm{abc}}$ \\
VII & DM AMHE $125 \mathrm{mg} / \mathrm{kg}$ & $153.75 \pm 2.97^{\mathrm{a}}$ & $295.63 \pm 23.87^{\mathrm{ab}}$ & $55.25 \pm 2.36^{\mathrm{b}}$ & $39.38 \pm 2.96^{\mathrm{abc}}$ \\
VIII & DM AMHE $250 \mathrm{mg} / \mathrm{kg}$ & $149.00 \pm 4.94^{\mathrm{ab}}$ & $293.00 \pm 13.51^{\mathrm{ab}}$ & $51.78 \pm 2.86^{\mathrm{b}}$ & $38.63 \pm 2.37^{\mathrm{abc}}$ \\
IX & DM AMHE $500 \mathrm{mg} / \mathrm{kg}$ & $148.63 \pm 4.55^{\mathrm{ab}}$ & $280.25 \pm 10.59^{\mathrm{ab}}$ & $62.91 \pm 1.77^{\mathrm{abc}}$ & $29.66 \pm 2.49^{\mathrm{bc}}$ \\
X & DM AME $125 \mathrm{mg} / \mathrm{kg}$ & $153.25 \pm 2.99^{\mathrm{a}}$ & $298.88 \pm 24.25^{\mathrm{ab}}$ & $56.11 \pm 2.62^{\mathrm{bc}}$ & $37.36 \pm 2.72^{\mathrm{abc}}$ \\
XI & DM AME $250 \mathrm{mg} / \mathrm{kg}$ & $149.88 \pm 4.24^{\mathrm{ab}}$ & $325.38 \pm 13.33^{\mathrm{a}}$ & $45.38 \pm 1.33^{\mathrm{b}}$ & $39.43 \pm 2.72^{\mathrm{abc}}$ \\
XII & DM AME $500 \mathrm{mg} / \mathrm{kg}$ & $164.38 \pm 3.53^{\mathrm{a}}$ & $321.50 \pm 10.06^{\mathrm{a}}$ & $58.88 \pm 1.80^{\mathrm{abc}}$ & $41.20 \pm 1.53^{\mathrm{abc}}$ \\
\hline
\end{tabular}

The values represent the mean \pm SEM. ${ }^{a}$ represents statistical significance $(p<0.05)$ compared with normal control. ${ }^{b}$ represent statistical significance $(p<0.05)$ compared with diabetic control. ${ }^{c}$ represent statistical significance $(p<0.05)$ compared with DM GB $0.5 \mathrm{mg} / \mathrm{kg}$. 
dation of unsaturated fatty acids, cholesterol and lipoproteins, increased lipid peroxidation leads to membrane damage and consequently organs dysfunction being this an important risk factor for atherosclerosis and coronary artery disease. ${ }^{44,46,48-49}$ Decreasing on lipid levels and consequently the reduction of lipid peroxidation were improved due to the high antioxidant potential of polyphenolic compounds that act by mechanisms of reaction inhibition in the peroxidation chain and could be reduce complication resulting from diabetes. ${ }^{48-49}$

\section{CONCLUSION}

The study confirms the traditional uses of Thai folklore recipe from $M$. pudica (MAI-YA-LAP) and A. indicum (KHOB-FUN-SRI) to improvement of diabetes. The recipe also prevents complications resulting from diabetes and improve the blood biochemistry. Further studies, isolations, purifications and investigation of the chemical constituent(s) of both plants responsible for the hypoglycemic effect should be undertaken in order to confirm and clarify the mechanism behind this activity.

\section{ACKNOWLEDGEMENT}

The research was partially supported by the Office of Thai Traditional Medical Knowledge Fund, Department of Thai Traditional and Alternative Medicine, Ministry of Public Health, Thailand.

\section{CONFLICT OF INTEREST}

The authors declare no conflict of interest.

\section{ABBREVIATIONS USED}

A. indicum: Abutilon indicum; M. Pudica: Mimosa pudica; AMA: Aqueous extracts; AMHE: Hydro-ethanol; AME: $80 \%$ Ethanol: GB: Glibenclamide; FBG: Fasting blood glucose levels; BUN: Blood urea nitrogen; CREA: Creatinine; TP: Total protein; Alb: Albumin; AST: Serum aspartate aminotransferase; ALT: Serum alanine aminotransferase; ALP: Alkaline phosphatase; TG: Triglycerides; TC: Total cholesterol; HDL: High-density lipoprotein; LDL: Low-density lipoprotein; DM: Diabetes mellitus; NM: Normal.

\section{REFERENCES}

1. American Diabetes association. diagnosis and classification of diabetes mellitus. diabetes care. 2009;32(suppl 1):s62-7.

2. American diabetes association. Standards of medical care in diabetes 2009 . Diabetes Care. 2009;32:Suppl s13-61.

3. Harrigan RA, Nathan MS, Beattie P. Oral agents for the treatment of type 2 diabetes mellitus: pharmacology, toxicity, and treatment. Ann Emerg Med. 2001;38:68-78.

4. Nazirogilu M, Butterworth P. Protective effects of moderate exercise with dietary vitamin $\mathrm{C}$ and $\mathrm{E}$ on blood antioxidative defense mechanism in rats with streptozotocin-induced diabetes. Can J Appl Physiol. 2005;30(2):172-85.

5. Manosroi J, Zaruwa Z, Moses, Manosroi W, Manosroi A. Hypoglycemic activity of Thai medicinal plants selected from the Thai/Lanna Medicinal Recipe Database MANOSROI II, Journal of Ethnopharmacology. 2011;138:92-8.

6. Khalid MS, Shah JK, Suresh D K, Singh RK, Reddy NIV, Kumar S. Evaluation of anti-diarrhoeal potential of ethanolic extract of Mimosa pudica leaves. IJGP. 2011; 5(1): 75-8.

7. Kannan S, Aravinth S, Sam E, Kumar J, Saminathan K, Suthakaran R, Ravi kumar M, Parimala DB. Wound healing activity of Mimosa pudica Linn formulation. Int J Chem Tech Res. 2009;11(4):1554-8.

8. Kokane DD, More RY, Kale KB, Nehete MN. Evaluation of wound healing activity of root of Mimosa pudica. J Ethnopharmacol. 2009;124:311-5.

9. Chandrashekar DK, Manthale DM. Invention of analgesic and anti-Inflammatory activity of ethanolic extract of Mimosa pudica Linn leaves. EJBPS. 2012;1(1):368.

10. Bum EN, Dawack DL, Schmutz M, Rakotonirina A, Rakotonirina SV, Portet $C$, et al. Anticonvulsant activity of Mimosa pudica decoction. Fitoterapia. 2004;75/34):309-14.

11. Chaddha VR, Kushwah AS, Shrivastava $V$, An importance of herbal drugs as antidiarrhoeal: areview. IMPACT: IJRANSS. 2013;1(7): 25-8.
12. Chowdhury SA, Islam J, Rahaman Mahfujur Md, Rahman Mostafizur Md, Rumzhum N, Sultana R, Parvin MN. Cytotoxicity, antimicrobial and antioxidant studies of the different plant parts of Mimosa pudica. SJPS. 2008;1(1\&2): 80-4.

13. Suneetha B, Pavan KP, Prasad KVSRG, Vidyadhara S, Sambasiva RKRS. Hepatoprotective and antioxidant activities of methanolic extract of Mimosa pudica roots against carbon tetrachloride induced hepatotoxicity in albino rats. IRJP. $2011 ; 1(1): 46-53$.

14. Rajendran R, Hemalatha S, Akasakalai K, MadhuKrishna $\mathrm{CH}$, Sohil BV, Sundaram MR. Hepatoprotective activity of Mimosa pudica leaves against Carbontetrachloride induced toxicity. J NAT PROD. 2009;2:116-22.

15. Sowmya A, Ananthi T. Hypolipidemic activity of Mimosa pudica Linn on butter induced hyperlipidemia in rats. AJPS. 2011;1(4):123-6.

16. Rajendran R, Krishnakumar E. Hypolipidemic activity of chloroform extract of Mimosa pudica leaves. AJMB. 2010;2(4):215-1.

17. SangmaTK, Meitei UD, Sanjenbam R, Khumbongmayum S. Diuretic property of aqueous extract of leaves of Mimosa pudica Linn. on experimental albino rats. J Nat Prod. 2010;3:172-8.

18. Sutar NG, Sutar UN, Behera BC. Antidiabetic activity of Mimosa pudica Linn in albino rats. J Herb Med. 2009;3(1):123-6.

19. Yupparach P, Konsue A. Hypoglycemic and Hypolipidemic Activities of Ethanolic Extract from Mimosa pudica L. in Normal and Streptozotocin-Induced Diabetic Rats. Pharmacogn J. 9(6):834-7.

20. Konsue A, Picheansoonthon C, Talubmook C. Fasting Blood Glucose Levels and Hematological Values in Normal and Streptozotocin-Induced Diabetic Rats of Mimosa pudica L. Extracts. Pharmacogn J. 2017;9(3):315-22.

21. Amalraj T, Ignacimuthu S. Hyperglycemic effect of leaves of Mimosa pudica Linn. Fitoterapia. 2002;73:351-2

22. Chuakul W, Saralamp P, Paonil W, Temsiririrkkul R, Clayton T, eds. Medicinal Plants in Thailand, Vol. 2. Bangkok: Amarin Printing and Publishing Public. 1997.

23. Nguyen OK, Nguyen DB. Investigational method for the extraction of natural compounds from Abutilon indicum L. Tap Chi Duoc Hoc. 2002(2):10-3.

24. Ahmed M, Amin S, Islam M, Takahashi M, Okuyama E, Hossain CF. Analgesic principle from Abutilon indicum. Pharmazie. 2000; 55: 314.

25. Seetharam YN, Chalageri G, Setty SR. Bheemachar. Hypoglycemic activity of Abutilon indicum leaf extracts in rats. Fitoterapia. 2002:73:156-9.

26. Kishan A R, Ajitha M, Rajanarayana K. Antidiabetic, antihyperlipidemic and free radical scavenging activities of an Ayurvedic medicine. Indian Drugs. 2000;37| 3):130-2.

27. Adisakwattana S, Pudhom K, Yibchok-anun S. Influence of the methanolic extract from Abutilon indicum leaves in normal and streptozotocin-induced diabetic rats. African Journal of Biotechnology. 2011;8(10):2011-5.

28. Krisanapun $C$, Peungvicha $P$, Temsiririrkkul $R$, Wongkrajanga $Y$. Aqueous extract of Abutilon indicum Sweet inhibits glucose absorption and stimulates insulin secretion in rodents. Nutrition Research. 2009;29(8):579-87.

29. Krisanapun C, Seong-Ho Lee, Peungvicha P, Temsiririrkkul R, Seung Joon Baek. Antidiabetic Activities of Abutilon indicum (L.) Sweet AreMediated by Enhancement of Adipocyte Differentiation and Activation of the GLUT1 Promoter. Evidence-Based Complementary and Alternative Medicine. 2011 (2011): 1-9.

30. Porchezhian E, Ansari S H. Hepatoprotective activity of Abutilon indicum on experimental liver damage in rats. Phytomedicine. 2005;12(1-2):62-4.

31. Parekh J, Chanda S. Antibacterial and phytochemical studies on twelve species of Indian medicinal plants. African Journal of Biomedical Research. 2007; 10:175-81

32. Chuakul W, Saralamp P, Paonil W, Temsiririrkkul R, Clayton T. Medical plants in Thailand Volume II. Bangkok: Amarin Printing and Publishing Public Co. Ltd.; 1997

33. Pushparaj PN, Low HK, Manikandan J, Tan BKH, Tan CH. Antidiabetic effects of Cichorium intybus in streptozotocininduced diabetic rats. J Ethnopharmacol. 2007; 111: 430-4.

34. Talubmook C. Effect of polysaccharide from Phellinus ignarius (L) Quel. On hematological values and blood cell characteristic in diabetic rats. JMST. 2008;22:42-5

35. Fisher J. Drugs and chemicals that produce diabetes. Trends in Pharmacological Sciences. 1985;6:72-5.

36. Junod A, Lambert AE, Stauffacher W, Renold AE. Diabetogenic action of streptozotocin: relationship of dose to metabolic response. Journal of Clinical Investigation. 1969;48:2129-39.

37. Eidi, A., Eidi, M., Esmaeili, E., Antidiabetic effect of garlic (Allium sativum L.) in normal and streptozotocin-induced diabetic rats. Phytomedicine. 2006;13:6249.

38. Odetola AA, Akinloye O, Egunjobi C, Adekunle WA, Ayoola AO. Possible antidiabetic and antihyperlipidaemic effect of fermented Parkia biglobosa (JACQ) extract in alloxan-induced diabetic rats. Clin Exp Pharmacol Physiol. 2006;33:80812.

39. Eidi A, Eidi M, Sokhteh M. Effect of fenugreek (Trigonella foenumgraecum L) seeds on serum parameters in normal and streptozotocininduced diabetic rats. Nutr Res. 2007;27:728-29.

40. Fang XK, Gao J, Zhu DN. Kaempferol and quercetin isolated from Euonymus 
alatus improve glucose uptake of 3T3L1 cells without adipogenesis activity. Life Sciences. 2008;82:615-22.

41. Padeea P, Nualkaewa S, Talubmookb C, Sakuljaitrongc S. Hypoglycemic effect of a leaf extract of Pseuderanthemum palatiferum (Nees) Radlk. in normal and streptozotocininduced diabetic rats. J Ethnopharmacol. 2010;132:491-6.

42. Ohaeri OC. Effect of garlic oil on the levels of various enzymes in the serum and tissue of streptozotocin diabetic rats. Biosci Rep. 2001;21:19-24.

43. Bakris GL. Diabetic nephropathy. What you need to know to preserve kidneyfunction. Postgrad. Med. 1993;93:89-90.

44. Narender T, Shweta S, Tiwari P, Papi, Reddy K, Khaliq T, et al. Antihyperglycemic and antidyslipidemic agent from Aegle marmelos. Bioorganic \& Medicinal Chemistry Letters. 2007;17:1808-11.

45. Maghrani M, Lemhadri A, Zeggwagh N, Amraoui M, Haloui M, Jouad H, et al. Effects of an aqueous extract of Triticum repens on lipid metabolism innormal and recent-onset diabetic rats. J Ethnopharmacol. 2004;90:331-7.

46. Tuvemo T, Ewald U, Kobboh M, Proos LA. Serum magnesium and pro-tein concentrations during the first five years of insulin-dependent diabetes inchildren. Acta Paediatr. 1997;86:7-10.

47. Alfy A, Ahmed A, Fatani A, Protective effect of red grape seed sproanthocyanidins against induction of diabetes by alloxan in rats. Pharmacol. Res. 2005;52:264-70.

48. Kamalakkannan N, Prince P. Antihyperglycaemic and antioxidant effect of rutin, a polyphenolic flavonoid, in streptozotocin-induced diabetic Wistar rats.Basic Clin. Pharmacol Toxicol. 2006;98:97-103.

49. Maghrani M, Lemhadri A, Zeggwagh N, Amraoui M, Haloui M, Jouad H, et al. Effects of an aqueous extract of Triticum repens on lipid metabolism in normal and recent-onset diabetic rats. J Ethnopharmacol. 2004;90:331-7.

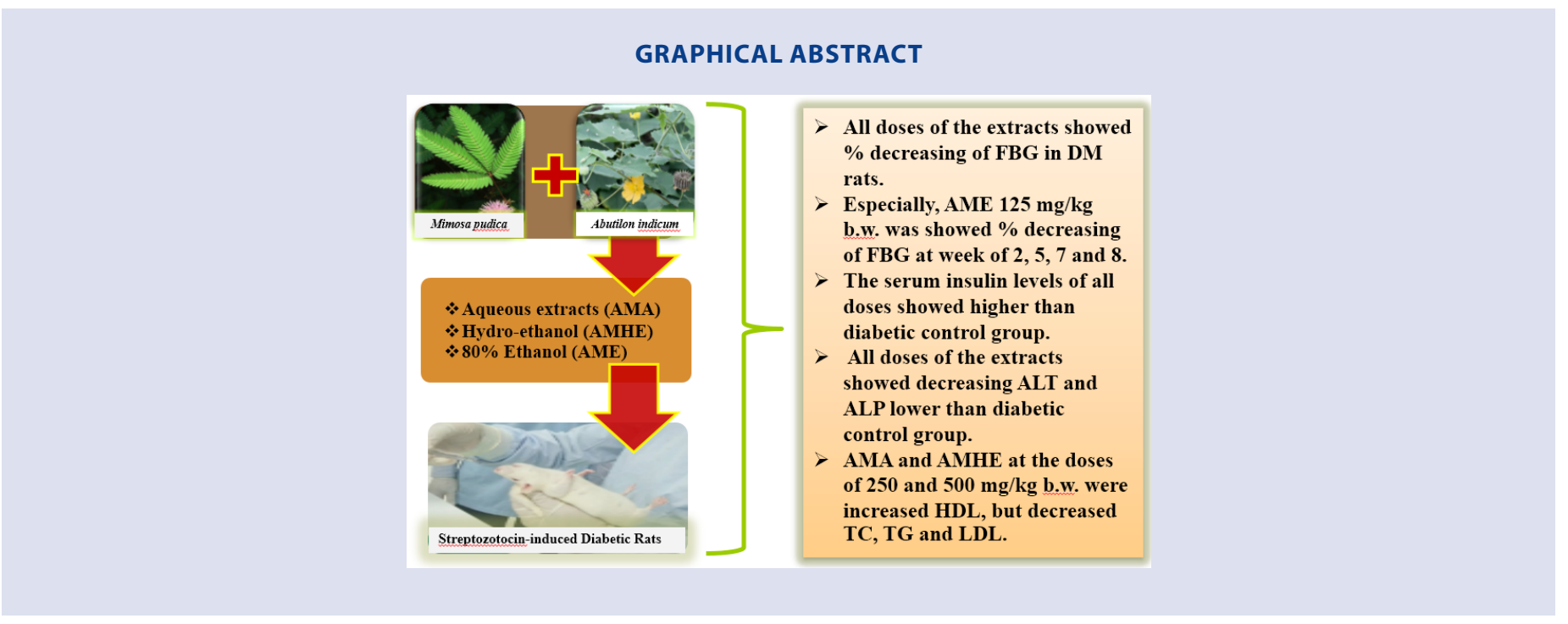

Cite this article: Konsue A, Talubmook C. Effect of Thai Folklore Recipe from Abutilon indicum and Mimosa pudica in StreptozotocinInduced Diabetic Rats. Pharmacog J. 2018;10(3):480-85. 